\title{
Ecotourism in the Reserva de la Biosfera de Los Tuxtlas (Veracruz, Mexico)
}

\author{
By Isis Arlene Díaz-Carrión * \\ Christoph Neger ${ }^{\dagger}$
}

Ecotourism aims at protecting the natural environment while at the same time bringing benefits to the local population. Therefore, it is often used as a conservation strategy in protected areas all over the world. However, the ways ecotourism is implemented vary greatly not only between different regions, even within one region there can be a large range of different approaches. The kind of strategy used subsequently determines its success regarding ecotourism's central goals of environmental conservation and development. Almost three decades ago, ecotourism was introduced to the area of the Los Tuxtlas Biosphere Reserve in the Mexican state of Veracruz. This was mainly driven by efforts of the public sector, which especially promoted community-based ecotourism initiatives. On the other hand, there have been several private attempts as well. Finally, ecotourism companies in the region also tried to network among each other - although to date with only little success. In this study, the authors take a look at how ecotourism developed in the area from its beginnings until now. This is carried out basically by indepth interviews with local actors involved in ecotourism as well as by direct observation. The main purpose of this research is to analyse and evaluate the steps in the region's ecotourism development and the different strategies used by the ecotourism companies. Furthermore, the authors try to identify ecotourism's effects in the region on the whole.

\section{Introduction}

The first considerable effort to conservation in Mexico happened with the declaration of the national park El Desierto de los Leones in 1917. According to the Natural Protected Areas Commission by the end of 2013, the number of protected natural areas under federal law had risen to a number of 176 , covering around $13 \%$ of the nation's territory. Among the various functions assigned to this kind of protected areas there is the use for recreational functions, ecotourism included.

In Mexico, ecotourism has been promoted in some protected areas during the last decades in order to promote protection of nature and biodiversity as

*Professor, Autonomous University of Baja California, Mexico.

${ }^{\dagger}$ Freelance Researcher, Graz Austria. 
well as to diversify the economy of rural areas with particular emphasis on poverty reduction.

Using a qualitative methodology the introduction and development of ecotourism in a protected area is revisited in order to analyse different strategies to promote ecotourism and the role played by different agents in the Reserva de la Biosfera de Los Tuxtlas, a natural protected area located in the South of the Mexican State of Veracruz where private and community-based ecotourism initiatives has been present since the last 3 decades.

This paper starts with giving a general background of ecotourism in Mexican natural protected areas. Subsequently, the paper introduces the Reserva de la Biosfera de Los Tuxtlas. After this, data derived in the fieldwork and the review of academic literature are presented and the outcomes of ecotourism in this protected area are discussed. Finally, the results are summed up by a conclusion.

\section{Ecoturism the protected Areas of Mexico}

According to Melo (2002), the biosphere reserves, along with national parks, are of special interest for the development of tourism activities. Obviously, tourism development within a protected area should be consistent with the principles of sustainable development and especially regardful of the area's ecological integrity (Weaver 2006, pp. 19-20).

Among the types of tourism recommended for natural protected areas, one particularly stands out: ecotourism. This activity is promoted in Mexico's protected natural areas as a tool for environmental education and as a strategy for diversification of the economic activities of the local population, thereby lowering the pressure on traditionally used natural resources and trying to eliminate poverty (Córdoba et al. 2004, p. 65). According to López \& Palomino (2008, pp. 39-42), in Mexico ecotourism emerges in the beginning of the 21 st century as a consequence of public policy addressing poverty as well as conservation of natural resources.

Implementation of tourism activities in Mexico's natural protected areas varies in intensity. While in some areas one can find characteristics of mass tourism, contrasting the aims of protection, in other protected areas tourism has been introduced to directly support conservation, not always with a successful result (Brenner \& San Germán, 2012, p. 137).

In some cases, large tour operators are promoting a conventional 'sun, sand and sea' product (Bringas \& Ojeda, 2000), while on the other hand in some areas tourism development is predominantly supported by small local communities (López \& Palomino, op. cit., p. 40). In 2006, a study analised tourism development in 83 natural protected areas. They were catalogued into categories, dependent on their state of development (incipient, planned, predatory and managed) and the kind of management of tourism in the area (explorative, preparative, reactive and proactive); the largest number of protected areas showed a predatory tourism development and a reactive 
management, while in only $10 \%$ of the areas tourism was qualified as planned with a preparative management (CONANP 2006a).

However, there are indeed efforts of several tourism agents to build synergies in order to develop and promote conservation tourism. Among those efforts the federal government has developed a national strategy for sustainable development of tourism in natural protected areas (CONANPa, 2006b). This strategy has been criticised by several tourism experts; however, it must be recognised as an initial effort to control and properly develop tourism (especially where tourism has already been present before the declaration of a protection status). The role of universities and NGOs has been very important in protected areas, these agents assisted the development of ecotourism in a variety of ways, mainly in generating information necessary for decision making and in observing the impacts of strategies on natural resources and communities (Paré \& Fuentes, 2007; Carmona et al., 2004).

\section{The Reserva de la Biosfera de Los Tuxtlas (RBT)}

Located in the South of the Mexican state of Veracruz $\left(18^{\circ} 34^{\prime}-18^{\circ} 36^{\prime} \mathrm{N}\right.$, $\left.95^{\circ} 04^{\prime}-95^{\circ} 09^{\prime} \mathrm{W}\right)$, with an extension of 155.122 ha. It was declared in 1998 in an effort to protect the remaining areas of tropical rainforest and cloud forest surrounded by the coastal region of the Gulf of Mexico (CONANP, 2006) (see Fig. 1). The region can be defined as a volcanic island, characterized mainly by low hills; there are two outstanding volcanic massifs, San Martín and Santa Marta, separated by low-lying land which contains two important water bodies, the Catemaco Lake and the Sontecomapan Lagoon (Siemens, 2006). The RBT lies at the northern limit of the range of tropical rainforest in the American continent; therefore, the region contains a mix of species from the tropics as well as from the temperate zone, which causes a high biodiversity (Ibarra et al. 1997).

Figure 1. Ecotourism projects in Los Tuxtlas (2014)

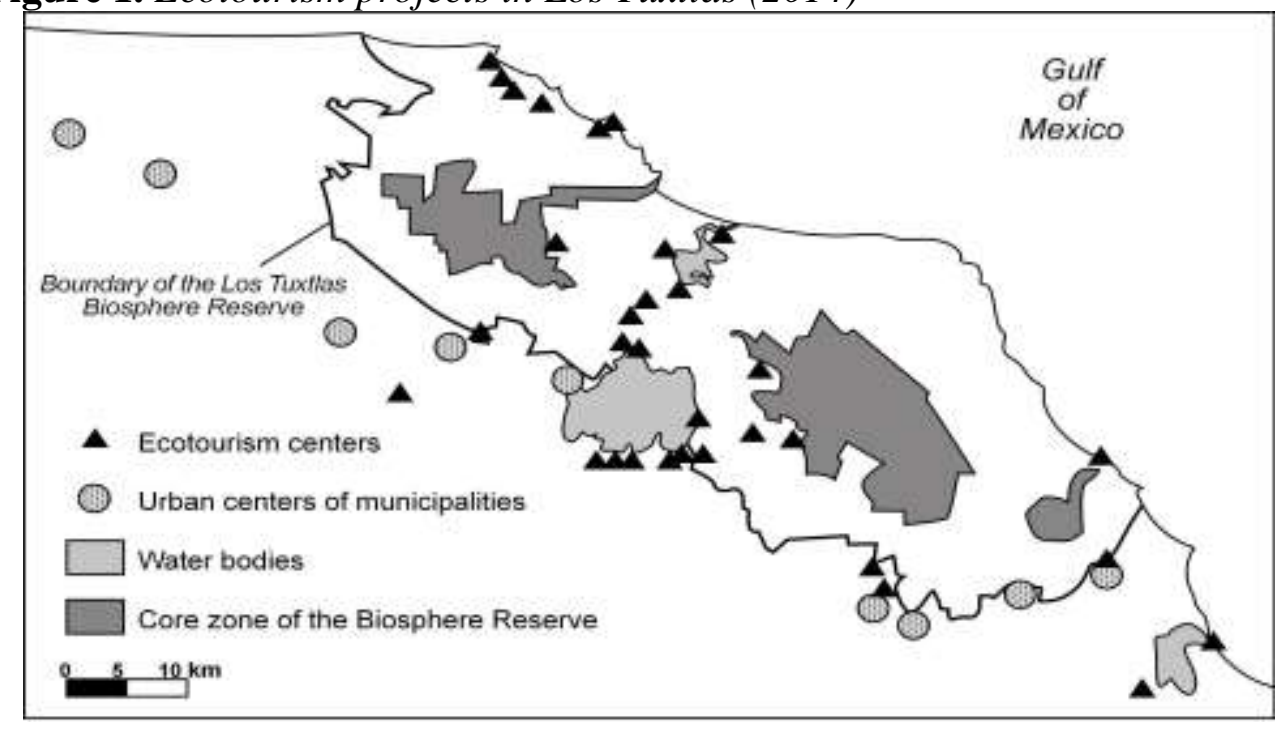


Historically, the region had reached different types of protection during the last 8 decades; during the last 30 years, these protection efforts intensified. Unfortunately, only about $20 \%$ of the original extent of tropical rainforest still remains, the rest had mainly been converted into pasture, especially in the 2nd half of the 20th century (Dirzo \& García, 1992; Guevara et al., 2004). Deforestation brings about a range of adverse effects, such as soil erosion, reduction in the biodiversity and the loss of important ecosystem services of the rainforest on a regional level such as water retention and protection against inundations or even on the global level regarding capture of carbon dioxide (CONANP, 2006a, pp. 16-17; 82-87). A further important threat to the area's flora and fauna is poaching and illegal logging as well as contamination in the ambit of human settlements. The less affected areas are the volcanic massifs, which form the Reserve's core areas: San Martín, Santa Marta and San Martín Pajapan.

In 2010 population within the boundaries of the biosphere reserve was 28.611 (own calculation based on INEGI [n.d.] and information given by the directorate of the RBT).. Most of the inhabitants are mestizos although indigenous people can be found, belonging to the ethnic groups of Nahua and Popoluca, in the South of the RBT. The economy of the area is mainly based on primary activities (íbidem). According to Paré \& Fuentes (op. cit., p. 16) there is a high degree of poverty among the area's population; moreover the process of implementation of environmental conservation after the declaration has been slow, while human pressure on the natural recourses is persisting.

\section{Implementation of Ecotourism in the RBT}

In the second half of the 1980s, the first pioneers in ecotourism appeared in the area. They were agents from urban origin (from within the Los Tuxtlas region or from the outside) who acquired land in a state of good conservation, easily accessible from the regional urban centers, and created small enterprises mainly offering services of guided walks as well as board and lodging.

The first private enterprise was Nanciyaga at the shore of Catemaco Lake which, despite the foundation of many other enterprises, still remains to be by far the economically most important ecotourism enterprise of the region, with day visitor numbers of over 100.000 in some years and about 40 full-time employees.

By the end of the 90s, then the first community-based ecotourism initiatives formed. This process was kindled by persons from NGOs and the academia, in rural communities interested in diversification of their sources of income by implementing activities compatible with the conservation of the remaining forests (Paré 2003, p. 274). The first one of them was Selva del Marinero in the peripheral community of López Mateos at the outskirt area of Sierra Santa Marta. While its economic success varied during the years, López Mateos is still the community with the highest degree of community member 
involvement. In 2012 about 40 of the 100 inhabitants of the community were officially engaged in the project.

Figure 2. The Ecotourism Product in the RBT
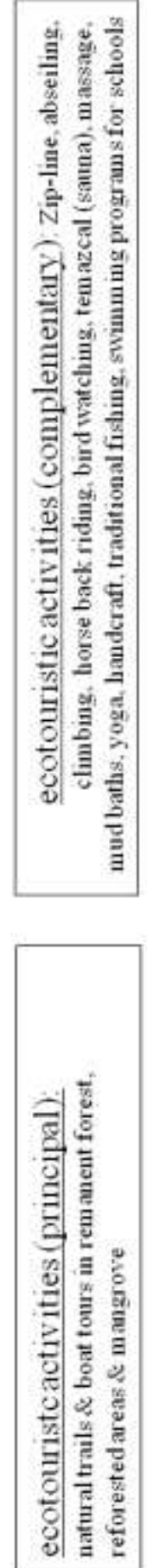

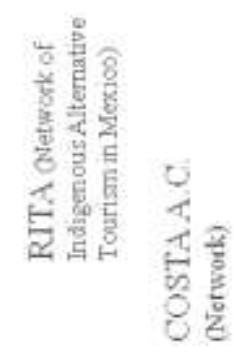

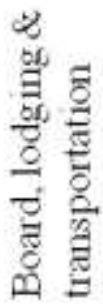

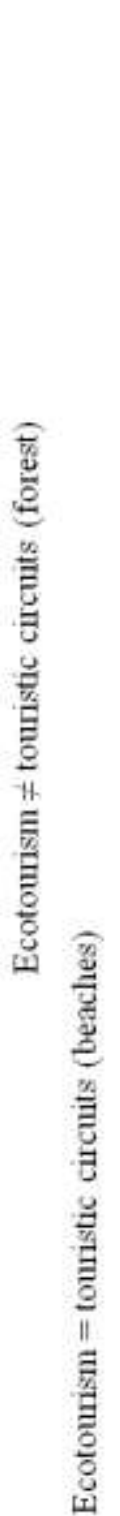

$\frac{\frac{s}{3}}{\frac{\Delta}{3}}$ $\uparrow \frac{0}{0}$

$\frac{0}{\circ}$

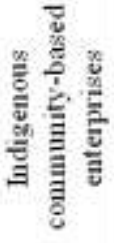

8
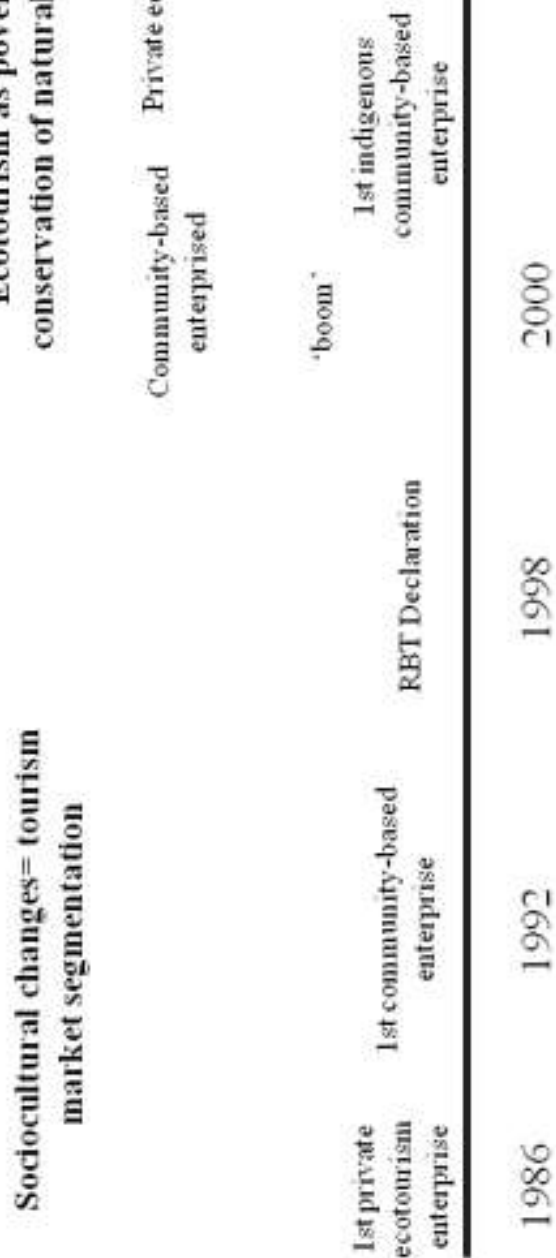

Source: Own elaboration based on the fieldwork

With the declaration of the area as Biosphere Reserve, in 1998, ecotourism in the area started to get institutionalized support. This policy had a strong 
impact in the tourism at the RBT, fomenting existing community-based initiatives and causing the foundation of new ones, all of them connected to at least one of several public programs. The main focus of these programs was to provide funding for the construction of touristic installations and capacity building. In the South of the RBT, almost all projects have been funded by the National Commission for the Development of Indigenous People (CDI), in the period 1998-2001 (Díaz, 2012). Following the upsurge of community-based ecotourism, during the last 7 years several small private enterprises started to offer basic touristic services mainly or secondary related to ecotourism as well (see Fig. 2).

During the last decade the ecotourism product has evolved from mostly nature trails and board in poor conditions (in some cases the service was provided with no proper installations) to a range of activities (Fig. 2) and the development of improved installations. In some cases the level of training is quite evident, for instance, some community-based enterprises have experienced some specialization for the guiding. Due to capacity-building programs as well as personal interest of the guides, some community-based enterprises nowadays count with well-prepared and specialized guides, for instance in the field of bird watching. Indeed, this does not apply for all the enterprises, however, during our fieldwork it was confirmed that almost everywhere the tourists receive at least some basic information about the importance of conservation in the RBT.

By the time being the majority of the ecotourism enterprises are concentrated in two areas, in the surroundings of Lake Catemaco and in the Northern coastal area of Los Tuxtlas. Furthermore, some enterprises are located in the indigenous areas in the South of the region and some close to the border of the core zones in the foothills of the volcanoes San Martín and Santa Marta. Within the core zone, nevertheless, no tourism installations can be constructed, this protected area can only be used for low impact activities such as hiking (CONANP 2006a, p. 138).

Private ecotourism enterprises are mainly connected with municipalities through secondary roads and located between the corridors CatemacoSontecomapan as well as along the coast. This location allows them to get an important market share of ecotourism and excursionists. However, there is also one private enterprise in a very peripheral location, the private protected area La Otra Opción which opened its doors to tourism in 2011 is only reachable by horse or quad-bike.

Most of the community-based enterprises are dispersed in the reserve, some are located in the main corridor and few of them are isolated in communities at the base of mountains. In the south of the RBT the pattern of distribution is more irregular since the main criteria for the establishment of ecotourism installation was more administrative and by considering in the first place the presence of indigenous population in the locality. In this part of the RBT ecotourism was also introduced as a government decision to principally fight poverty and preserve natural resources in indigenous communities. 


\section{Efforts of Working Together}

Several authors point to the many potential benefits of cooperation of tourism enterprises in a region (Paré \& Lazos 2003, p. 204; Stradas 2000, p. 162; Wearing \& Neil 1999, pp. 109-118). Synergy effects, for instance, could be used in common efforts for nature conservation, in representing common political interests as well as in forming a partnership for marketing, thereby promoting the region as a whole with lots of different attractions instead of only single enterprises.

The first and, to date, most important effort in this direction at the RBT was the RECT (Network of Community-based Ecotourism of Los Tuxtlas), a process which was initiated by the authority of the RBT in 2003. In the beginning 8 projects took part, four private projects from communities at the Northern coast of the Los Tuxtlas region and four community-based enterprises in the municipality of Catemaco, amongst others the initiative of Selva del Marinero which had been mentioned above.

The networked served as a platform for capacity building programs and at the same time promoted a common marketing strategy, with an internet website, folders, appearance in radio programs, attendance at tourism fairs and even a selling point in Mexico City. Without doubt, a lot of the things done in the RECT brought about considerable benefits for its participating enterprises. However, in the end it seems as if the project had failed to be a sustainable approach, since most enterprises left the network - some even after legal disputes - only two of them still remain. The distrust created by the rupture of the network is still present and constrains further attempts of networking. Common criticisms of the RECT are that it focused too much on standardisation, at the expense of the enterprises' individuality, and that it made them overly dependent on an external advisor who managed the process.

In 2010 a new effort was undertaken to form an alliance of all ecotourism initiatives present in the municipality of Catemaco which contains by far the highest number of ecotourism enterprises among the municipalities which form part of the RBT. The alliance started as a result of a workshop undertaken by representatives from NGOs and the academia. In the beginning, more than 20 private and community-based initiatives took part. The biosphere reserve's authority, deterred by the occurrences in the RECT, never participated actively in this process. After two years already the alliance was abandoned, because of lack of interest and incapacity of its members to define common goals. Its only outcomes were a singular publication of a promotional magazine and the participation in one fair. One obstacle for working together may lie in the decision-making structure of the community-based initiatives. A representative of an initiative cannot approve a common agreement with other enterprises without before consulting all of the members of his own initiative, making the process longer than usual.

Another alliance of only community-based initiatives is still working in the South of the RBT. It is part of the national cooperation network RITA (Network of Indigenous Alternative Tourism in Mexico) which started in 2002 with 32 indigenous community-based initiatives. By 2012 it had 160 initiatives 
integrated in 11 regional networks; seven of the community-based initiatives located in RBT were part of the southeast regional network. However, this effort is primary aimed to commercialization and only secondary on product development. South community-based initiatives in the RBT have had a more difficult process with more confrontation among agents than those located in the North.

The last network which operates in the RBT is COSTA, A.C., a network that integrates both private and community-based initiatives related to ecotourism along the Northern part of the coastline of Los Tuxtlas. The network started as an individual effort by a non-local woman residing in one of the communities, who invited all small enterprises of the area to develop sustainable initiatives together. In this case, conflicts started due to money and by 2010 the network was nearly inactive; however, due to individual efforts it seems to have started functioning again by the beginning of 2012 .

\section{Constraints for the Projects' Effectiveness}

Ecotourism development in the RBT faces several restrictions, which explain why beside Nanciyaga the number of people employed in private initiatives has stayed low. In community-based initiatives ecotourism has, in all cases, stayed an additional economic activity, the initiatives' members are still engaged in other activities such as agriculture. Some of the most important constraints are:

- Seasonality of tourism (Lein, 2011, p. 50), due to the region's climatic conditions - the rainy season lasts from June to February, especially from July to November precipitation can be heavy (Soto, 2004, p. 195) - and due to the Mexican holiday times.

- Missing motivation and proactivity among the members of the community-based initiatives (Lein, 2011, op. cit., p. 50; interviews) and problems in organising an enterprise due to generally low levels of education; missing knowledge of English and other languages constraints the ability to receive international tourists.

- Problems with accessibility, most roads in the region are missing maintenance.

- In some cases the emergence of ecotourism creates conflicts within the local community, between those who want to develop this touristic activity and therefore protect the natural resources and those who want to continue with activities such as logging and hunting (cp. Tauro (2009) who describes the development in the community of Ruiz Cortines near the core zone in the north of the RBT).

- Missing cooperation among those involved in the planning and development of ecotourism (Neger 2013).

- The ecotourism product is not well structured, and the selling process is deficient especially among community-based initiatives 
whose efforts are limited in several ways (e.g. most communitybased initiatives do not have an internet access).

- Support by governmental institutions is often short-lived, there is little continuity and coordination between different public institutions is in need of improvement. Los Tuxtlas misses a comprehensive, long-term strategy for ecotourism development (Neger 2013).

In the last years, tourism even decreased in community-based initiatives; private initiatives showed a strong decrease as well. Owners of some private enterprises recently seem to be losing interest in ecotourism and try to find other sources of economic income or sell their enterprise.

There are different reasons that could explain this situation. Troubles started in May 2009 when influenza A(H1N1) was first reported in Mexico; for some community-based initiatives May is the month when college ecotourists from Mexico City arrive; one of the community-based initiatives expected two groups of about 100 ecotourists, a second one was expecting a group of 50 ecotourists, but all groups cancelled due to the influenza-crisis.

Floods were another event during 2009 and 2010 that contributed the drop of ecotourists; according to several managers and members of ecotourism initiatives interviewed even though floods were not a general problem in most of the RBT, tourists from Mexico City associated incorrectly the situation of other municipalities from Tabasco with Veracruz and that match contributed to the decrease of arrivals during the months that followed spring of 2009.

Another reason for the decrease of arrivals can be found in the region's decreased security, due to violence related to drug trafficking and other illegal activities. According to the people interviewed by the authors, this violence never affected any tourists directly; however, negative coverage in the media deters many potential visitors from coming (Neger, 2013, op. cit.).

New reforms proposed in 2013 by the federal government were followed by large conflicts, especially with teacher unions who in fall of the same year undertook protest actions like temporarily closing roads. This seems to have frightened off many visitors, ecotourism enterprises reported that several already booked tours had been cancelled. To make matters worse, at the same time in Catemaco some communities where ecotourism projects are located were almost inaccessible for several weeks due to flooding of the access road.

\section{Benefits of Ecotourism in the Region}

Regardless those limitations, ecotourism is considered as an activity that generates positive effects. According to our interviews ecotourism enterprises have been very good allies in the conservation process engaging in environmental education and reforestation (Andrade, RBT Personnel \& Hernández, PROFEPA). This idea of secondary support for conservation through ecotourism in the region is also affirmed by other local stakeholders: "...ecotourism does not directly contribute to conservation, but it has the 
positive effect that people try to earn their income from ecotourism and not from poaching and logging" (Swanson, NGO).

The potential of ecotourism is evident in the RBT not only between official agents: "Ecotourism helps a lot in awareness raising among population" (Hernández, PROFEPA), but also among ecotourism initiatives: "For me... this little space of rainforest is alive due to the owner who bought some land and instead of cutting the trees bet high for conservation through ecotourism" (Pedraza, initiative manager) and for ecotourists: “...people of community-based initiatives played an important role in communicating the importance of conservation among the community as well as the visitors" (Mendez, ecotourist). A survey undertaken by García (2010) in two of the region's community-based enterprises underlined this positive effect on the visitors' ecological awareness.

In fact, environmental impacts vary largely between enterprises. One important contribution by some of the projects is to protect a certain space of land as a private or communitarian protected area. This guarantees a much higher degree of conservation than simply being located within the Los Tuxtlas Biosphere Reserve, which is often ignored by land owners and local authorities. The largest protected area of this kind is the communitarian reserve of López Mateos, where the initiative Selva del Marinero is located, with 120 ha. This land is part of the common land of the Ejido community and was declared officially as an ecological easement.

Some enterprises have undertaken efforts in reforestation, especially the private initiatives, for instance, La Otra Opción and Rancho Los Amigos each claim to have reforested about 60 ha. However, this reforestation was mainly financed by private money and public funds, especially in the case of La Otra Opción there had been no direct contribution by ecotourism, since touristic activity still hasn't developed in this remote place as a considerable source of economic income (Neger, 2013).

Other positive activities include environmental education for schools from within the region and cooperation with the Mexican Environmental Protection Agency (PROFEPA). Members of community-based ecotourism enterprises, for instance, participate actively in PROFEPA's voluntary community committees for supervision of environmental crimes. Some initiatives - like Nanciyaga, Selva del Marinero or La Otra Opción - also receive animals which had been confiscated from illegal traffickers.

\section{Conclusion}

Ecotourism at RBT has been implemented following different strategies, either private or community-based ecotourism enterprises developed ecotourism activities ranging from general to, sometimes, specialized services. Regardless the importance of private and NGO's funding, the role played by governmental funds in the implementation and development of ecotourism is 
evident not only in the case of community-based initiatives but also in the private ones.

Some cooperation efforts have been organized among different ecotourism agents, however, they did not succeed in order to bring about considerable promotion or a long-term strategy for the development of the activity.

Enterprises work isolated making success far more difficult for community-based initiatives, especially for those facing accessibility limitations and who feels disappointed with the lack of visitors and the restrictions of conservation and the economic restrictions of the region.

Outstanding positive results are efforts of reforestation and conservation; for one private enterprises ecotourism has been very productive economically.

Ecotourism at the RBT has not solved economic diversification problems nor assured conservation issues faced in the region; the benefits are punctual and always under negotiation. In order to promote ecotourism, tourism agents should cooperate among themselves to create a long-term planning and to manage a trademark to sell to the national and international market taking advantage of the geographical location of the region and improving dynamic factors related to the ecotourism product. Governmental agencies, especially CONANP which manages the RBT, are urged to resume their initial support to the region's ecotourism and provide leadership for its further process of development.

\section{References}

Brenner, L. \& San Germán, S. (2012). Local Governance for ecotourism in the Reserva de la Biosfera Mariposa Monarca, Mexico. Alteridades, 22 (44):131-146 [in Spanish].

Bringas, N. \& Ojeda, L. (2000). Ecotourism: a new form of mass tourism? Economía, Sociedad y Territorio. 11 (7):373-403 [in Spanish].

Carmona, G; Morales, J. \& E. Rodríguez (2004). Management Plan for the Sontecomapan mangroves, Catemaco, Veracruz, Mexico: a strategy for the conservation of natural resources. Madera y Bosques 10(2):5-23 [in Spanish].

Comisión Nacional de Áreas Naturales Protegidas (CONANP) (2006a). "Management Plan: Reserva de la Biosfera Los Tuxtlas". ed. CONANP, Mexico City [in Spanish].

(2006b). "National strategy for Sustainable Tourism Development and Recreation in Natural Protected Areas in Mexico" ed. CONANP. Mexico City [in Spanish].

"Natural Protected Areas". Available at http://www.conanp.gob.mx/que hacemos/ [13 february 2014] [in Spanish].

Córdoba, J.; García de Fuente, A.; Córdoba, M. \& E. Ayala (2004). Local-impacts of global politics: Celestún and "its" Reserva de la Biosfera (Yucatán, Mexico). Anales de Geografía, 24: 55-78 [in Spanish].

Díaz, I. (2012). Gender and alternative tourism: Approaching empowerment. [in Spanish]. PhD diss, Universidad Complutense de Madrid.

Dirzo, R. \& M.C. García (1992). Rates of deforestation in Los Tuxtlas, Veracruz, México. Conservation Biology, 6(1): 84-90. 
García, M. (2010). The Potential of Community-based Ecotourism Projects as Environmental-Education-for-Sustainability Centers. A case study of Los Tuxtlas Community-based Ecotourism Network (Mexico). MBA diss, King's College.

Guevara, S., Laborde, J. \& G. Sánchez-Ríos (2004). "Deforestation”. In: Guevara, S. at al. (ed.). Los Tuxtlas: The landscape of the mountain range. [in Spanish]. 85108. Instituto de Ecología, Xalapa.

Ibarra G.; Martínez M.; Dirzo, R. \& J. Núñez (1997). "Vegetation”. In González, E. et al. (ed.) Los Tuxtlas Natural History. [in Spanish]. 61-85. UNAM. Mexico City.

INEGI (n.d.): Population and housing census 2010. results for localities with less than 5 thousand inhabitants. Available at: http://www.inegi.org.mx/sistemas/consulta _resultados/m5mh.aspx?c=28004 (10 april 2014) [in Spanish].

Lein, J. (2011). Creation of acceptance for biosphere reserves through ecotourism. An analysis of the perception of the Reserva de la Biosfera Los Tuxtlas, Mexico, by local ecotourism enterprises. [in German]. BSc diss, University of Greifswald.

López, G \& B. Palomino (2008). Public politics and ecotourism in native communities in Mexico. Teoría y Práxis 5:33-50 [in Spanish].

Melo, C. (2002). Natural Protected Areas in Mexico in 20 $0^{\text {th }}$ Century . [in Spanish]. UNAM . México City.

Neger, C. (2013). Ecotourism and sustainable regional development: case studies from Los Tuxtlas/Mexico. Akademikerverlag. Saarbrücken [in German].

Paré, L. (2003). "Community-based ecotourim and environmental management" In: Paré \& Lazos (ed.). Rural school and Community Organization: Local Institutions for Development and Environmental Management [in Spanish].. 261311. UNAM-Plaza Valdés S.A. de C.V. Mexico City.

Paré, L. \& E. Lazos (2003). Rural school and Community Organization: Local Institutions for Development and Environmental Management. [in Spanish]. UNAM-Plaza Valdés S.A. de C.V. Mexico City.

Paré, L. \& T. Fuentes (2007). Environmental Governance and Public Politics en Natural Protected Areas. Lessons from Los Tuxtlas [in Spanish]. UNAM. Mexico City.

Siemens, A. (2004). The Landscapes. In: Guevara et al. (ed.). Los Tuxtlas: The landscape of the mountain range. 41-58. Xalapa: ed. Instituto de Ecología

Soto, M. (2004). The Climate. In: Guevara et al. (ed.), Los Tuxtlas: The landscape of the mountain range. [in Spanish]. 195-198. Instituto de Ecología. Xalapa.

Stradas, W. (2000). "Ecological Economy. Ecotourism in the practice of nature projects in Mexico and Belize. Approaches for the promotion of protected areas through sustainable and market-oriented tourism management". German Association for Technical Association [in Spanish]

Tauro, A. (2009). From conservation to care. Perception and oral history of changes in an Ejido's landscape. Reserva de la Biosfera Los Tuxtlas, Veracruz-Mexico. [in Spanish]. BSc diss, Universidad Nacional de Lanús

Wearing, S. \& J. Neil (1999). Ecotourism: Impacts, Potentials and Possibilities. Elsevier Butterworth-Heinemann, Oxford.

Weaver, D. (2006). Sustainable Tourism: Theory and Practice. Elsevier ButterworthHeinemann, Oxford. 